\title{
Stirring System Design for Automatic Coffee Maker Using OMRON PLC and PID Control
}

\author{
Ashadi Setiawan 1, Alfian Ma'arif 2,* \\ Department of Electrical Engineering, Universitas Ahmad Dahlan, Jl. Ringroad Selatan, Kragilan, Tamanan, Banguntapan, \\ Bantul, Daerah Istimewa Yogyakarta 55191, Indonesia \\ 1 ashadi1700022036@webmail.uad.ac.id; ${ }^{2}$ alfianmaarif@ee.uad.ac.id \\ * Corresponding Author
}

ARTICLE INFO

Article history

Received 23 September 2021

Revised 18 October 2021

Accepted 19 October 2021

Keywords

Programmable Logic Controller; PLC Omron;

DC Motor;

PID Control;

Angular Speed

\section{ABSTRACT}

The implementation of the use of PLC in this study was designed for a small scale in the process of stirring coffee drinks at a speed of 600 RPM. To get a stable speed so that the water does not overflow, a control system is needed. To get optimal results, a system design that can control the stirring speed is arranged automatically using a Programmable Logic Controller (PLC). This system is designed using a rotary encoder sensor C38S6G5-600B-G24N as a speed reader obtained from the movement of the motor, DC Motor JGA25-370 12V as an actuator or stirrer. PLC OMRON CP1E-NA20DR-A is used as a motor speed control device using the Proportional Integral Derivative (PID) algorithm to control the system according to the setpoint entered. The motor speed control system with the PID algorithm shows a system response that works well according to the researchers' expectations. The response of the system obtained is fast enough to achieve a stable speed with a small overshoot value. Thus this system was successfully designed to control the stirring process of coffee drinks automatically and produce stable stirring by giving a set point of 600 RPM at the parameter constant Proportional band is $720 \%$; Integral time is $1.6 \mathrm{~s}$, and Derivative time is $0.2 \mathrm{~s}$ with a rise time value is $1.3 \mathrm{~s}$; settling time is $11 \mathrm{~s}$; overshoot is $1.1 \%$, and steady-state error is $0.5 \%$.

This is an open-access article under the CC-BY-SA license.

\section{Introduction}

Until now, the development of technology has played a very important role in various aspects of life [1][2]. The development of information technology can be a breakthrough in the field of artificial intelligence that is able to give birth to new information technology in production activities that are controlled automatically with computer technology [3][4]. Rapid technological developments have had a major influence on the way of thinking of industrial engineering science by viewing integrated systems more broadly as a global network between industries [5][6]. Advances in technology can provide great change effectiveness and can facilitate human work on a large and small scale [7]. Along with the many human needs, everything is demanded to be instant [8]. In everyday life, for example, in the manufacture of coffee drinks. Coffee is one of the drinks that are in great demand by almost all groups of people 
[9], but currently, it is still mostly done manually. In addition, the serving manual requires estimating the amount of coffee and sugar that must be added to a cup of glass [10].

In serving coffee, there is a way to make it easier to make, namely by designing a control system. Moreover, it can be used automatically using a microcontroller [11]. The process of controlling the system with a microcontroller can control the on-off condition of a machine automatically so that it produces good quality [12]. Automatic control can be carried out using various types of controllers, one of which is using a Programmable Logic Controller (PLC) [13]. PLC-based systems in the industrial world that are able to operate quickly and accurately can improve quantity and quality in production [14]. PLC can be used to control various types of machines or processes through digital and analog input/output modules [15]. The implementation of using PLC in this study is designed for small scales such as daily life in making coffee drinks, especially in the stirring process. The rotation of the motor for automatic coffee mixing using PID will control the content of each composition in the container [16]. In addition, the stable rotation of the motor can keep the stirred ingredients from overflowing and stay in the container.

PLC has been used in many systems such as in battery management systems [17], Induction motor [18], Magnetic levitation systems [19], Biodiesel [20], Rubber Drying Machine [21], Smart Home systems [22], Liquid Level Control [23], Solar Power System [24]. PID has been used to control Magnetic levitation system [25], DC Motor [26][27], Hydraulic Transplanting Robot [28], Biomass Microwave [29], wind turbine [30], Hydroxy Generator [31], Mobile Robots [32], robot manipulators [33], UAV [34]. Some of these explanations are used to underlie in designing a Stirring System for Automatic Coffee Makers Using OMRON PLC and PID Control using PIDAT(191) instructions to control motor speed. PID control system is a control system that is widely used in industry [35][36][37] because of its reliability in controlling motor speed [38], especially in the mixing process. With the PIDAT(191) instruction, there is no need to make mathematical formulas in the PLC program because this instruction has complete features and automatically calculates the control signal output based on the parameters entered.

The related work to control the DC motor has been done before. Some of them is Linear Quadratic Regulator [39], Fractional Order PID [40], PID Control [41][42], PID Control [43], Fuzzy Logic Controller [44], State Observer [45]. However, the research only uses simulation, not hardware implementation. This study contributes hardware designed a system to control the stirring process of coffee drinks automatically using rotary encoder sensor C38S6G5-600BG24N is to measure motor speed. The DC Motor JGA25-370 12V is to drive the stirrer, and PLC OMRON CP1E-NA20DR-A is a system control device and produces stirring at a set point of 600 RPM. There is some section in the research. The first is an introduction, the second is method that consist of system design and algorithm. The third is result and discussion and the last is conclusion.

\section{Methods}

\subsection{System Design}

Two parts of system design consist of hardware design and software design. The hardware design is made in the form of block diagrams and system wiring diagrams, while the software design is made in the form of flow diagrams.

\subsubsection{Hardware Design}

The hardware design is made in the form of a block diagram - the three pieces of hardware consisting of a sensor unit, a control system, and an actuator. The hardware design block diagram is shown in Fig. 1. This design control system uses PLC OMRON-CP1E-NA20DR-A to control and process rotary encoder sensor reading data to measure motor speed. The actuator used is a DC motor to drive the stirrer. DC Motor Speed is regulated by the PWM (Pulse Width Modulation) method. PLC provides an analog voltage which is then converted by the Voltage to 
the PWM module into a \% duty cycle to drive the motor. PC/Laptop is used to create ladder diagrams using CX-Programmer software and HMI on CX-Designer, which can be communicated with PLC using USB 2.0 and RS232 cables.

In order to produce optimal motor speed, a PID control system is made on the motor. The purpose of this control system design is to adjust the motor speed so that it can reach the set point according to the input given so that the motor can rotate at a stable speed. The block diagram of the motor control system is shown in Fig. 2. The results of the rotary encoder sensor readings are used as PV values which are then processed with PID control on the PLC to give control commands to the actuator according to the given set point.

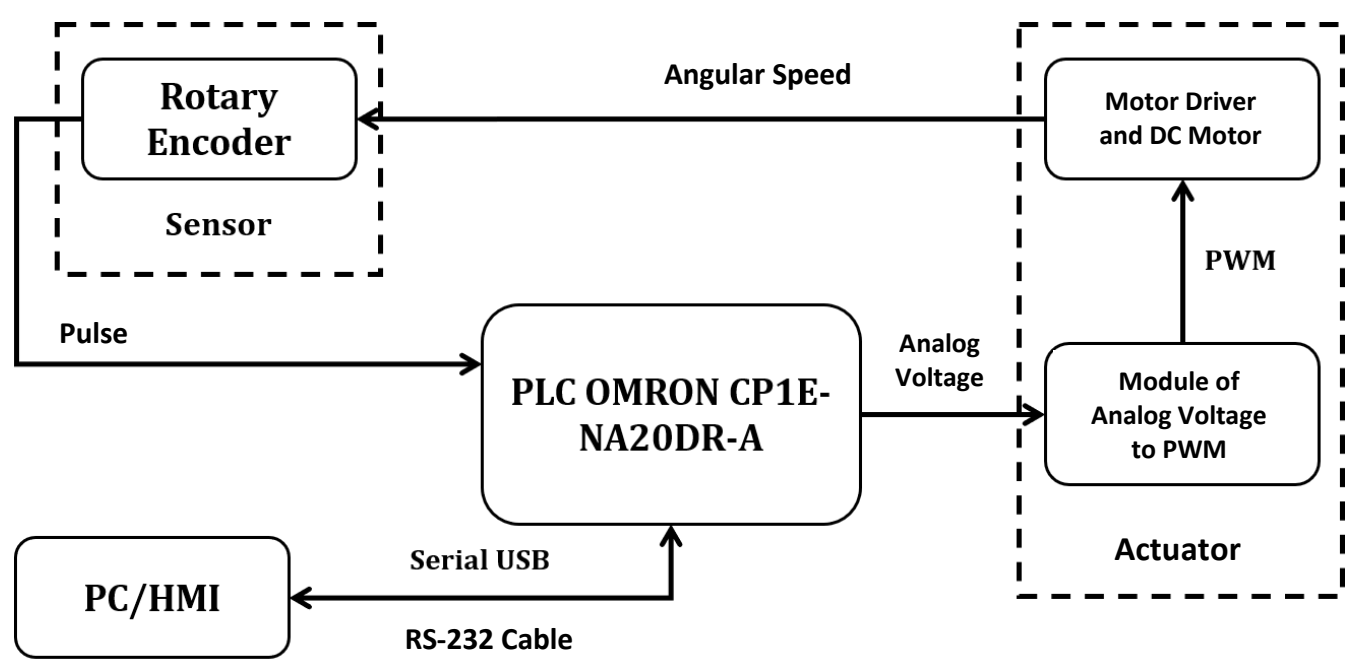

Fig. 1. System Block Diagram

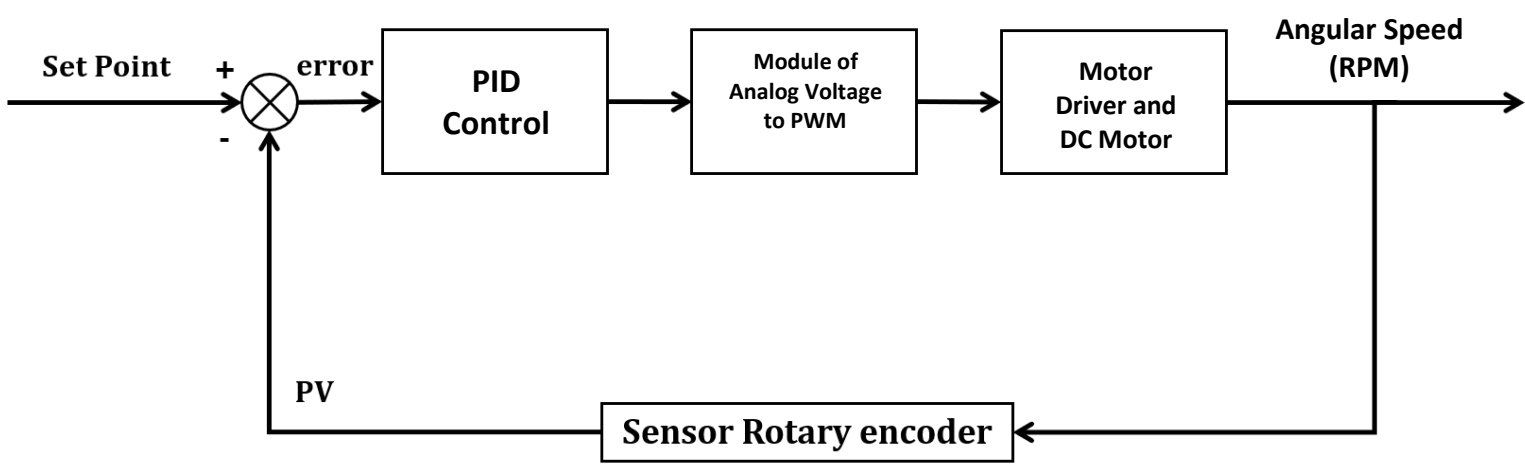

Fig. 2. Control System Block Diagram

\subsubsection{Wiring Diagram}

To make it easier to understand the system design, the wiring diagram is shown in Fig. 3. PLC gets 220V AC supply voltage. In addition, DC Power Supply is also used to supply other components such as rotary encoder sensors, Voltage to PWM modules, and DC motors. The rotary encoder sensor provides output in the form of pulses. Voltage to PWM module gets analog voltage input from PLC and converts to \% duty cycle as output to drive DC Motor. The details of the system input and output units are shown in Table 1. 
Table 1. Input-Output System

\begin{tabular}{clll}
\hline No. & \multicolumn{1}{c}{ Component } & \multicolumn{1}{c}{ Input } & \multicolumn{1}{c}{ Output } \\
\hline 1 & Sensor Rotary encoder C38S6G5-600B-G24N & $\begin{array}{l}\text { Power Supply: 24V DC } \\
\text { VCC: 5V DC; GND: 0 }\end{array}$ & Pulse of 24V DC \\
\hline 2 & PLC OMRON CP1E-NA20DR-A & $\begin{array}{l}\text { Power Supply: 220V AC } \\
\text { CIO 00: Pulse of 24V DC }\end{array}$ & CIO 190: analog 0-5V \\
\hline 3 & Module of Analog Voltage to PWM & $\begin{array}{l}\text { Power Supply: 12V DC } \\
\text { Input Signal: 0-5V DC }\end{array}$ & PWM Signal of 0-100\% \\
\hline 4 & DC Motor JGA25-370 & PWM: 12V 0-100\% & Angular Speed of 0-1000RPM \\
\hline
\end{tabular}

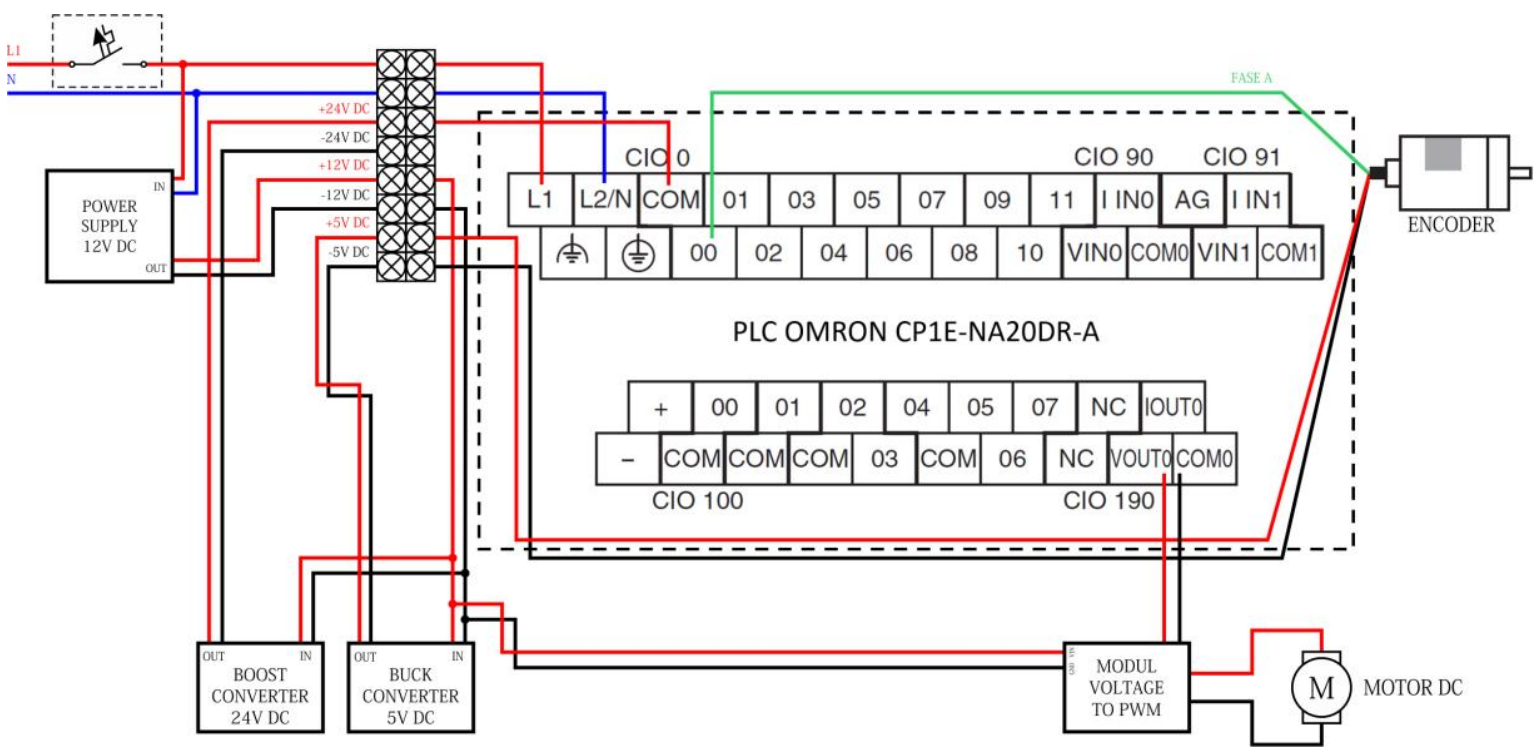

Fig. 3. System Wiring Diagram

\subsubsection{Algorithm}

The software design consists of 2 stages, namely the design of the motor control program flow diagram and the design of the Human Machine Interface (HMI). The motor control program flow diagram is shown in Fig. 4. The workflow of the motor control program begins with the reading of the motor speed value by the rotary encoder sensor. Then the scaling is done so that it is displayed in the form of RPM on the HMI. The scaling result obtained is used as the PV (Present Value) value for further processing by the PIDAT(191) instruction. The mode used is selected between manual or autotuning. Manual mode is done by entering the SV (Set Value) value or often known as the setpoint, PID parameter, and sampling time. Autotuning mode is done by providing a setpoint value, sampling time, and arbitrary PID parameters to assist in the process of activating the autotuning bit. The values that have been entered will be processed by the PIDAT(191) instruction to generate the MV (Manipulated Variable) value as the system output command to drive the motor according to the given set point.

\subsubsection{Human Machine Interface (HMI) Design}

The HMI design was made using the CX-Designer software. The HMI display is in the form of a motor controller page containing PID parameters, \% analog output, resolution values as well as a control graph shown in Fig. 5. This HMI is used to observe the measured speed value of the rotary encoder sensor, which is displayed with the RPM graph, enter the setpoint, sampling time, and PID parameters and activate the autotuning function. The system response can be observed through the resulting graph and log data which can be saved in the form of a .csv file. 


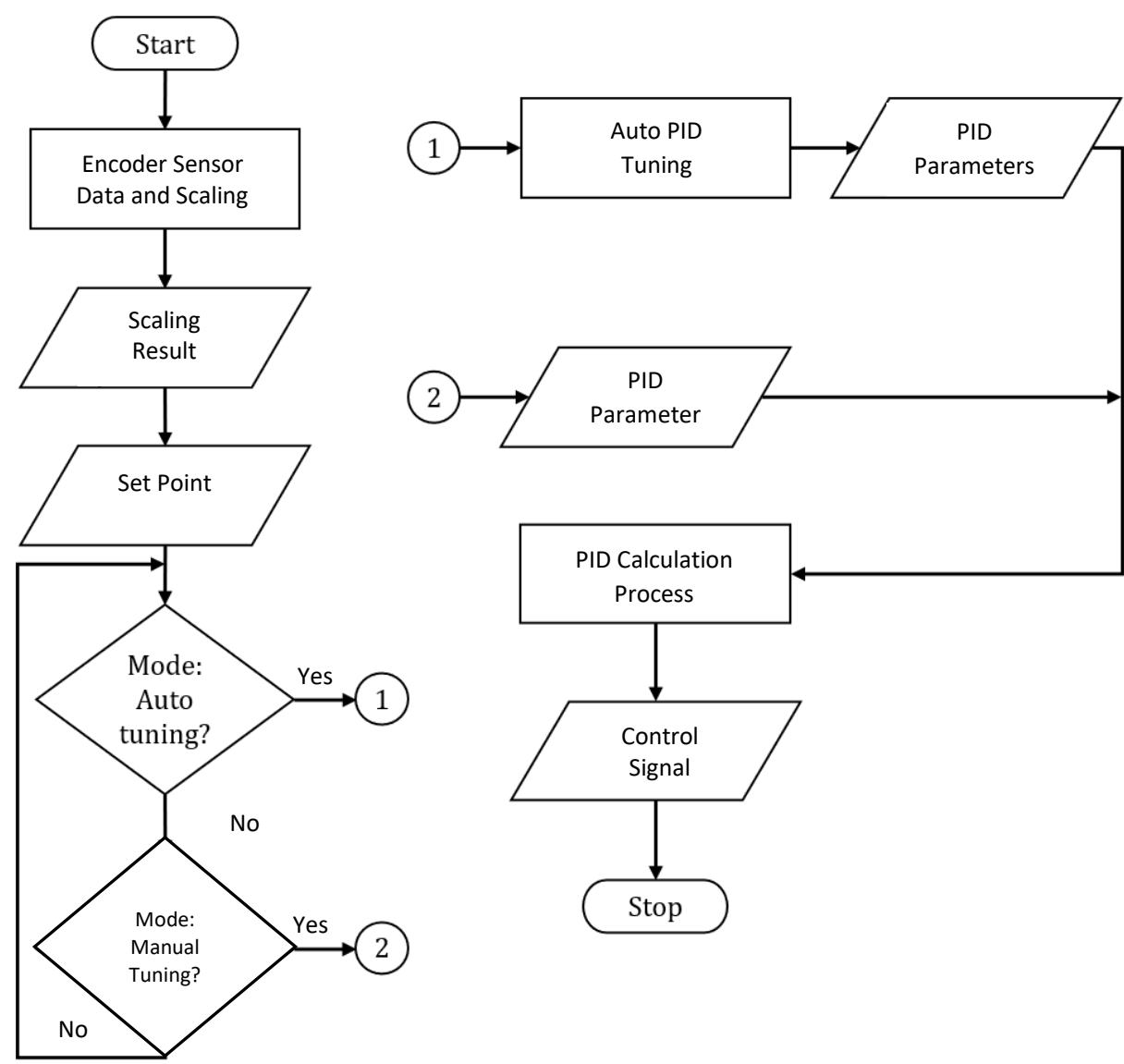

Fig. 4. Motor Controller Program Flowchart

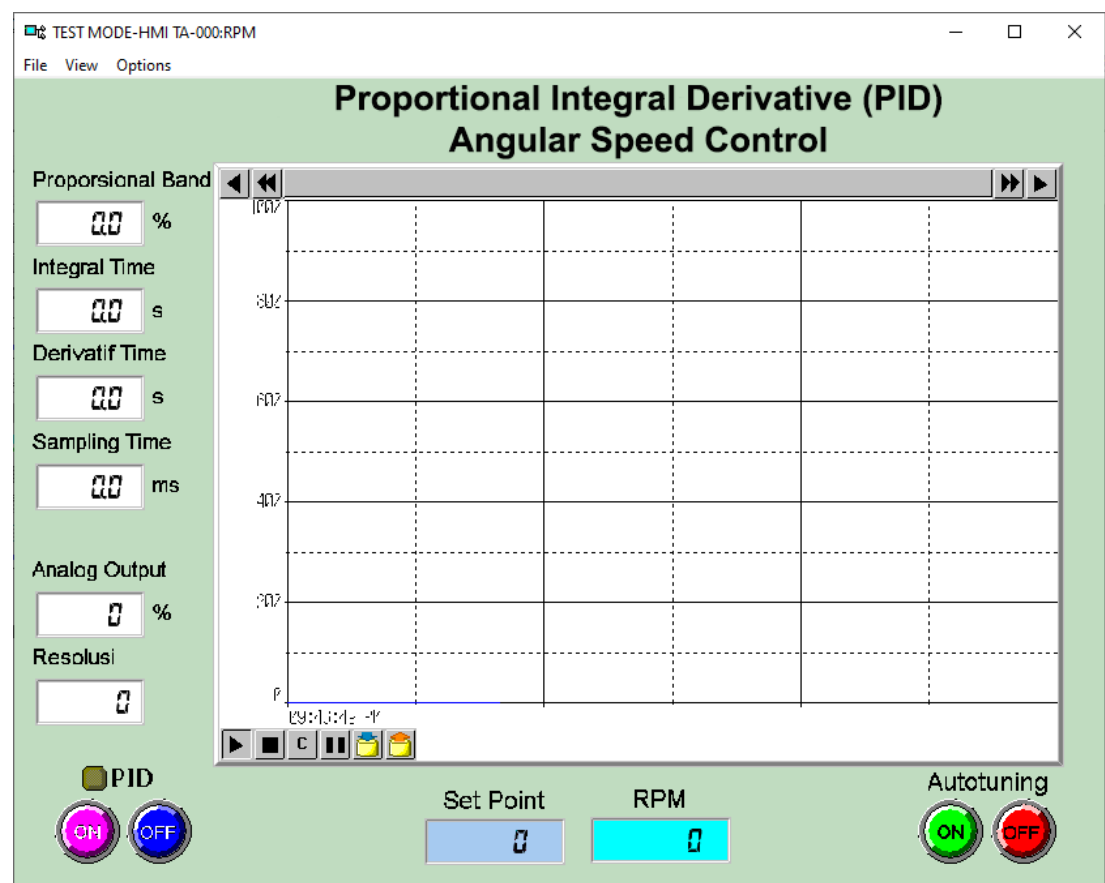

Fig. 5. Motor Controller HMI Display

Unlike the PID constants in general, such as the Proportional constant $\left(K_{p}\right)$, Integral constant $\left(K_{i}\right)$, and Derivative constant $\left(K_{d}\right)$ [46][47], the PIDAT(191) instruction in the PLC program uses PID parameters such as Proportional Band $(P B)$, Integral Time $\left(T_{i k}\right)$, and Derivative Time $\left(T_{d k}\right)$ [48]. The Proportional Band $(P B)$ equation is 


$$
P B=100 / K_{p}
$$

Integral Time $\left(\mathrm{T}_{\mathrm{ik}}\right)$ equation is

$$
K_{i}=\frac{K_{p}}{T_{i k}}
$$

Derivative Time $\left(\mathrm{T}_{\mathrm{dk}}\right)$ equation is

$$
K_{d}=K_{p} \times T_{d k}
$$

Where PB is Proportional Band (\%), $K_{p}$ is Proportional constant, $K_{i}$ is Integral constant, $T_{i k}$ is Integral Time (s), $K_{d}$ is Derivative constant, and $T_{d k}$ is Derivative time (s).

\section{Result and Discussion}

The results and discussion of this research include the manufacture of hardware, testing of motor speed control consisting of a Proportional Integral (PI) controller and a Proportional Integral Derivative (PID) controller.

\subsection{Hardware Manufacturing}

Hardware manufacture in this study consists of several main components, namely rotary encoder sensors, DC motors, and Voltage to PWM modules, and motor drivers that are shown in Fig. 6. There is a module of analog voltage to PMW, the Mosfet IRF540 as Motor Driver and Rotary Encoder Sensor.

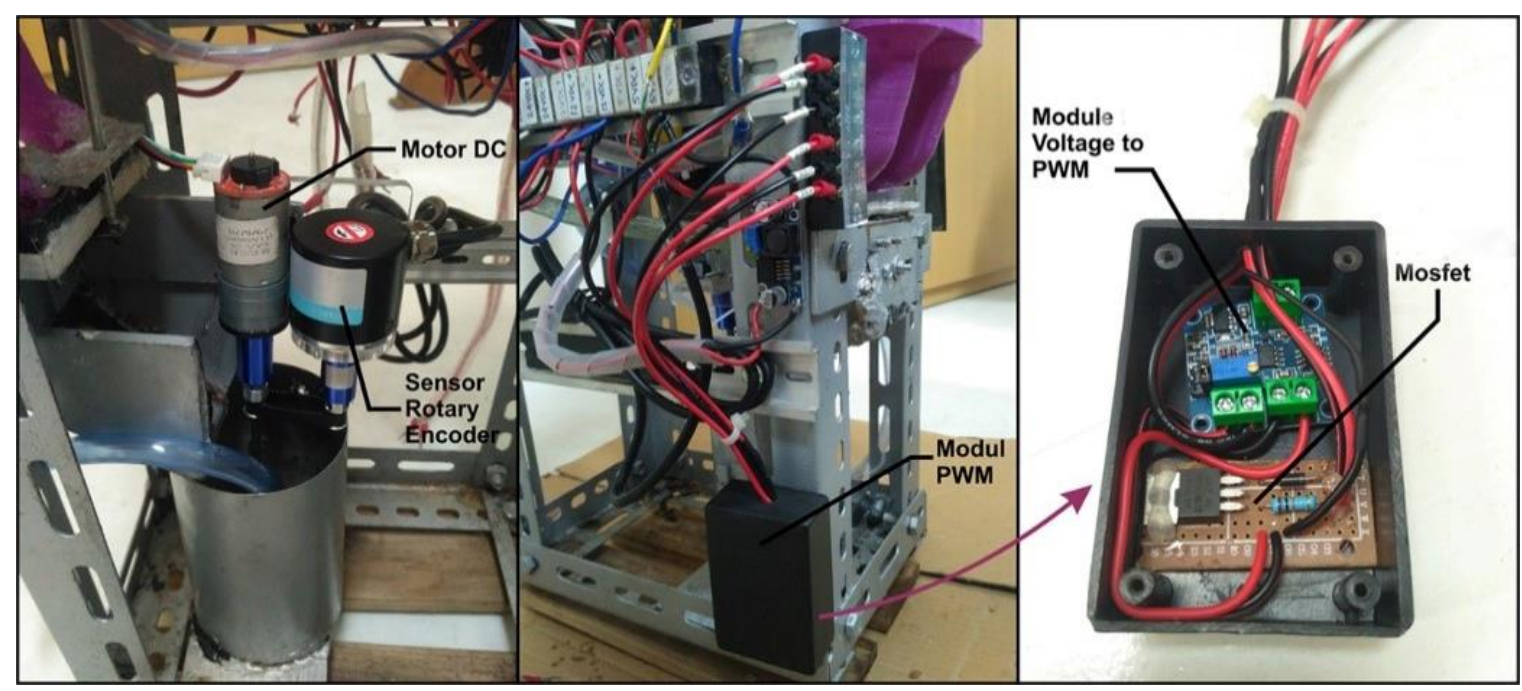

Fig. 6. Motor Control Hardware

\subsection{PI Control Testing}

Testing of motor speed control using a Proportional Integral (PI) controller was carried out by trial and error method by entering various parameters for three trials. This test was carried out on a motor that drives a coffee drink stirrer containing $200 \mathrm{ml}$ of water and a mixture of 50 $\mathrm{g}$ of sugar and coffee with a set point of $600 \mathrm{RPM}$ and a sampling time of $40 \mathrm{~ms}$. The test results are shown in Fig. 7.

The results of the system response from this test are stored in the form of a .csv file to observe the motor speed every second and analyzed using Matlab to get the response of the control system. The results of the analysis are shown in Table 2, and the comparison of the three graphs is shown in Fig. 8. From the results of the analysis using Matlab, motor speed control produces the most stable system response at parameters $\mathrm{PB}=500 \% ; \mathrm{T}_{\mathrm{ik}}=0.6 \mathrm{~s}$ with rise time value $=1.1 \mathrm{~s}$; settling time $=8.4 \mathrm{~s}$; overshoot $=52.6 \%$; and steady-state error $=0.8 \%$. 


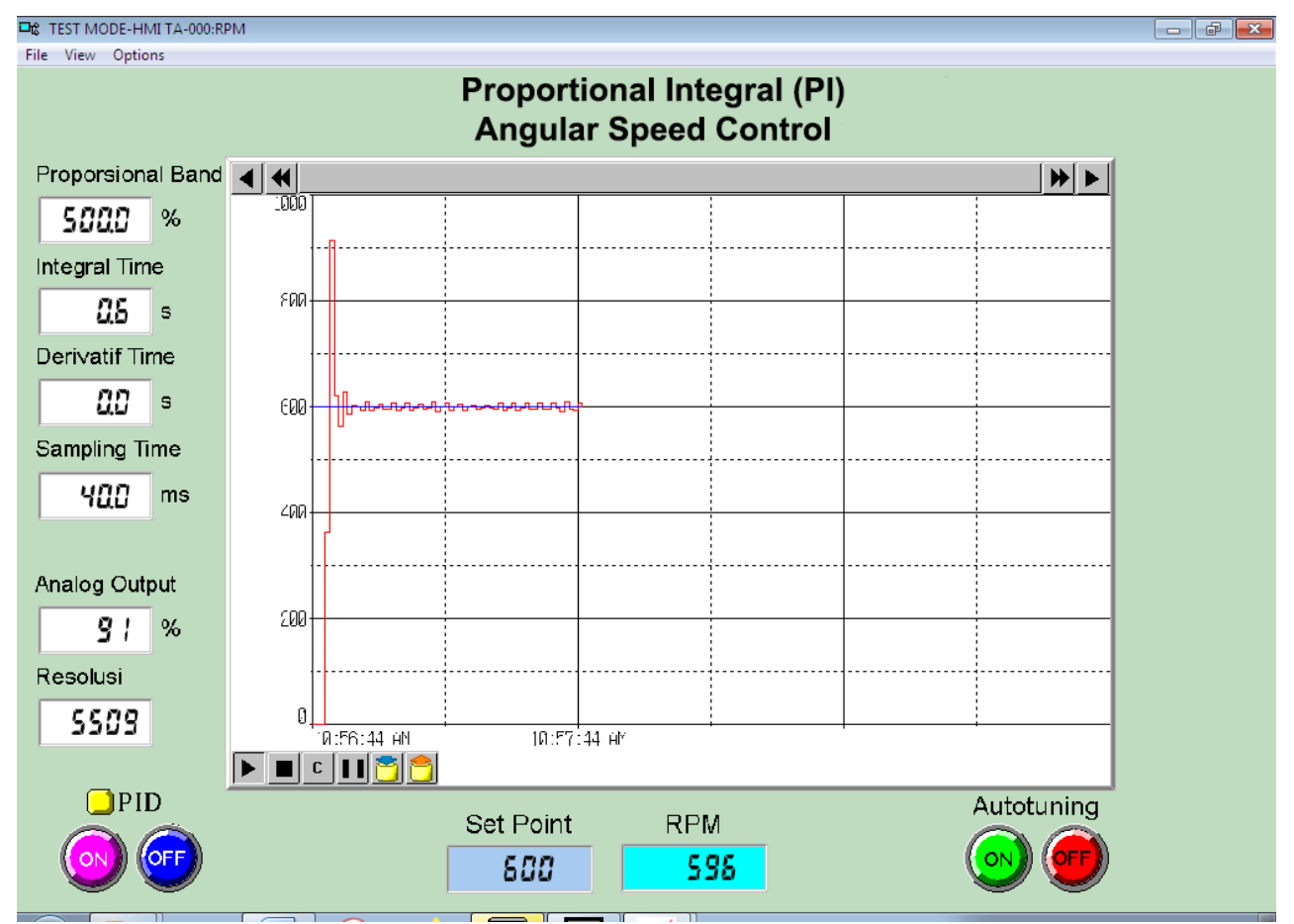

Fig. 7. PI Control Result

Table 2. PI Control Result

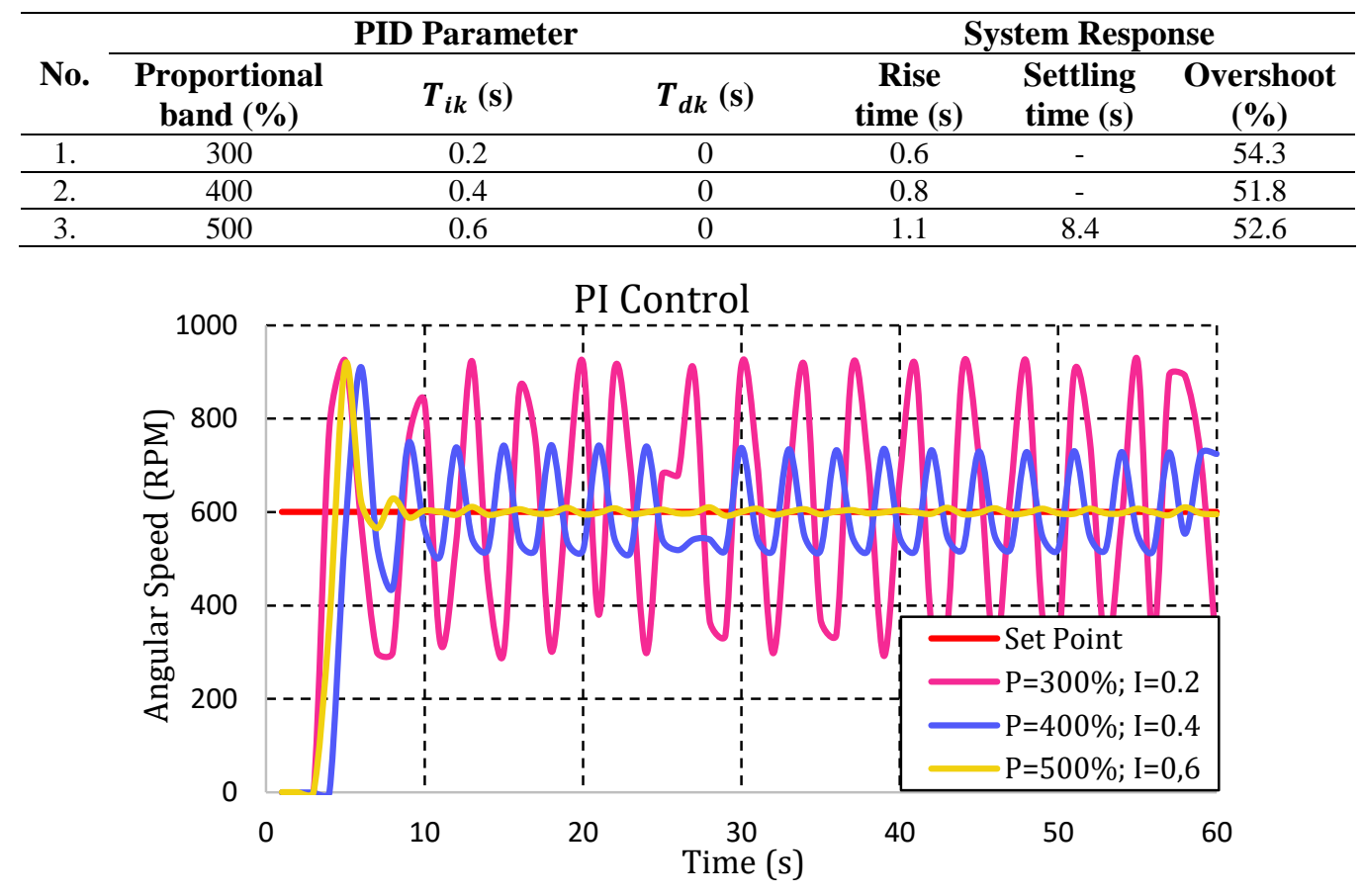

Fig. 8. PI Control Testing Result

\subsection{PID Control Testing}

Testing of motor speed control using a Proportional Integral Derivative (PID) controller was carried out by trial and error method for three trials. This test was carried out on a motor that drives a coffee drink stirrer containing $200 \mathrm{ml}$ of water and a mixture of $50 \mathrm{~g}$ of sugar and coffee with a set point of $600 \mathrm{RPM}$ and a sampling time of $30 \mathrm{~ms}$. The test results are shown in Fig. 9. The blue line is the set point or reference value, and the red line is the angular speed system response. 


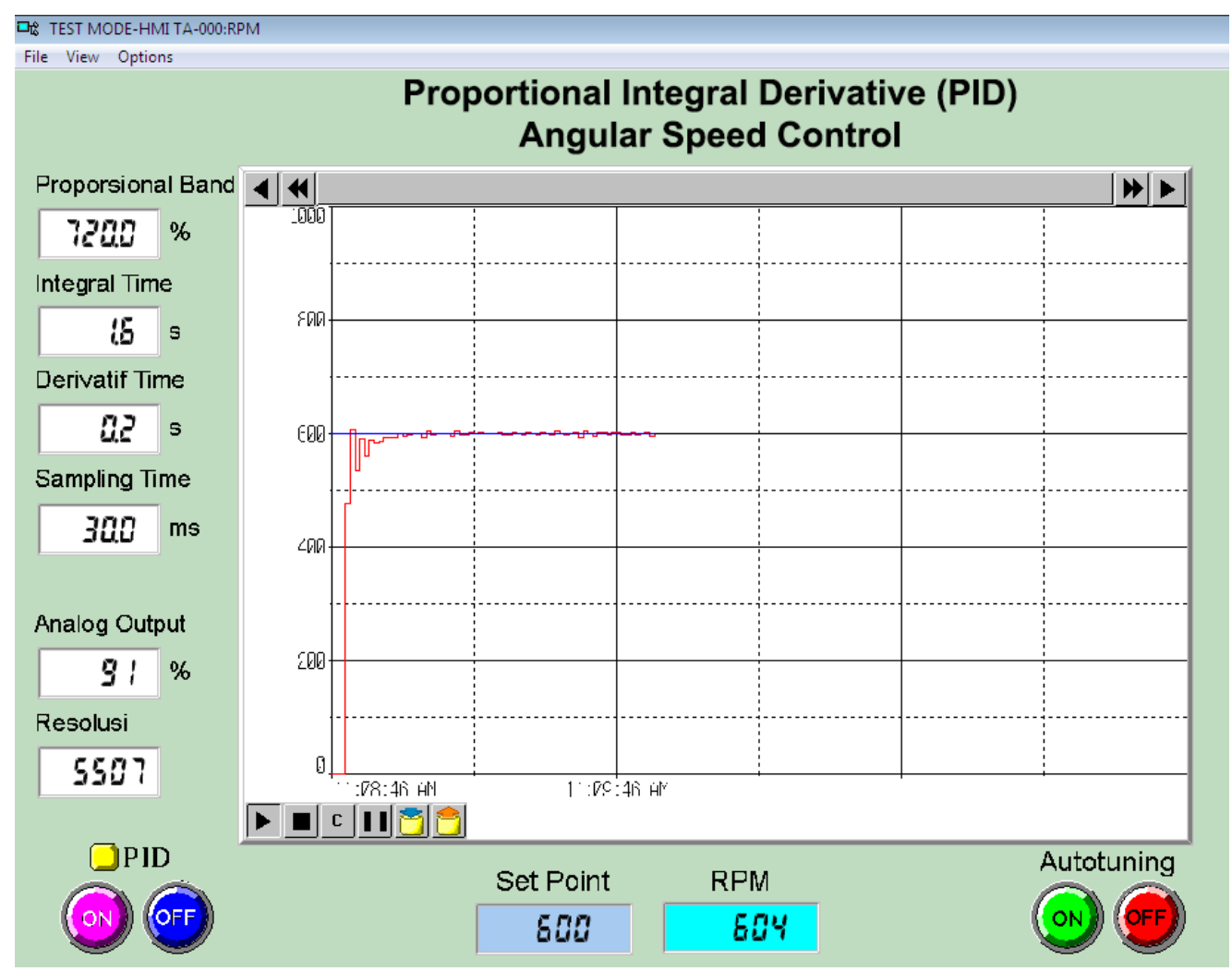

Fig. 9. PID Control Result

The results of the system response from this test are stored in the form of a .csv file to observe the motor speed every second and analyzed using Matlab to get the response of the control system. The results of the analysis are shown in Table 3 , and the comparison of the three graphs is shown in Fig. 10.

Table 3. PID Control Testing Result

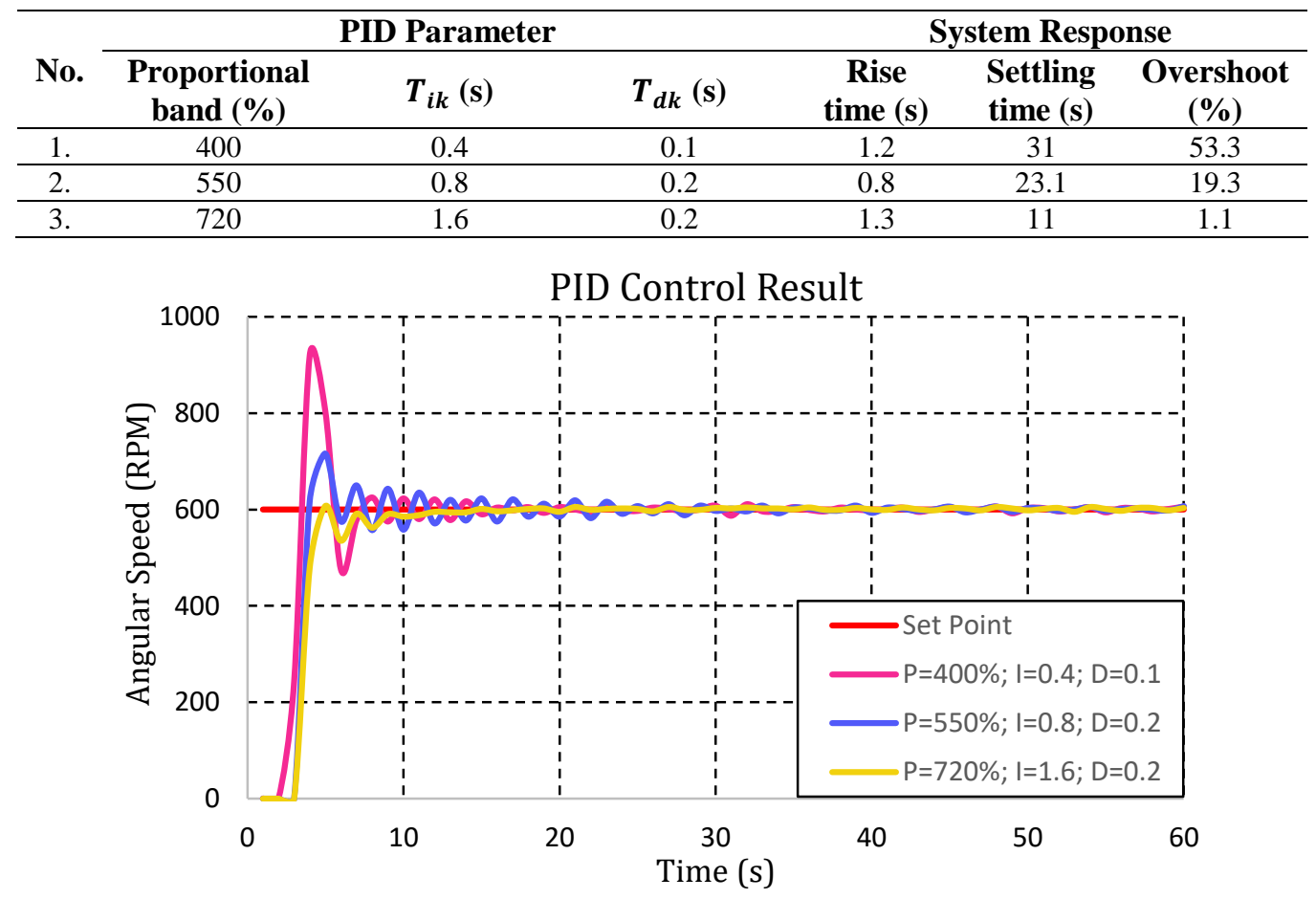

Fig. 10. PID Control Testing Result 
From the results of the analysis using Matlab, motor speed control produces the most stable system response at parameters $P B=720 \% ; T_{i k}=1,6 \mathrm{~s} ; T_{d k}=0.2 \mathrm{~s}$ with rise time value $=1.3 \mathrm{~s}$; settling time $=11 \mathrm{~s}$; overshoot $=1.1 \%$; and steady state error $=0.5 \%$.

\section{Conclusions}

The system design in this study succeeded in applying the motor control method using PLC OMRON CP1E-NA20DR-A as a system controller device. The results of motor control using a PI controller show that the system response is the most stable at the value of $P B=500 \% ; T_{i k}=$ $0.6 \mathrm{~s}$ with rise time value $=1.1 \mathrm{~s}$; settling time $=8.4 \mathrm{~s}$; overshoot $=52.6 \%$; and steady-state error $=0.8 \%$. The results of motor control using a PID controller show that the system response is the most stable at the value of $\mathrm{PB}=720 \% ; T_{i k}=1.6 \mathrm{~s} ; T_{d k}=0.2 \mathrm{~s}$ with rise time value $=1.3 \mathrm{~s}$; settling time $=11 \mathrm{~s}$; overshoot $=1.1 \%$; and steady-state error $=0.5 \%$. Based on the test results obtained, there are still shortcomings that can be improved. Suggestions given to further researchers are that they can improve the PID control system with PID tuning methods such as Ziegler-Nichols, Cohen-Coon, and so on so that PID parameters are obtained that can be used as reference values for the next tuning process.

Supplementary Material: The video abstract for the system can be seen in the URL https://youtu.be/r4CCmZnw90E

Author Contribution: All authors contributed equally to the main contributor to this paper. All authors read and approved the final paper.

Funding: This research was funded by Universitas Ahmad Dahlan.

Acknowledgment: The author would like to thank everyone that helped to finish and to improve the paper quality.

Conflicts of Interest: The authors declare no conflict of interest.

\section{References}

[1] Z. Lv and N. Kumar, "Software defined solutions for sensors in 6G/IoE," Computer Communications, vol. 153, pp. 42-47, Mar. 2020. https://doi.org/10.1016/j.comcom.2020.01.060

[2] M. A. Ahad, S. Paiva, G. Tripathi, and N. Feroz, "Enabling technologies and sustainable smart cities," Sustainable Cities and Society, vol. 61, p. 102301, Oct. 2020. https://doi.org/10.1016/j.scs.2020.102301

[3] S. Singh, P. K. Sharma, B. Yoon, M. Shojafar, G. H. Cho, and I. H. Ra, "Convergence of blockchain and artificial intelligence in IoT network for the sustainable smart city," Sustainable Cities and Society, vol. 63, p. 102364, Dec. 2020. https://doi.org/10.1016/j.scs.2020.102364

[4] H. Hamdan, "Industri 4.0: Pengaruh Revolusi Industri Pada Kewirausahaan Demi Kemandirian Ekonomi," Jurnal Nusantara Aplikasi Manajemen Bisnis, vol. 3, no. 2, p. 1, 2018. https://doi.org/10.29407/nusamba.v3i2.12142

[5] H. Cañas, J. Mula, M. Díaz-Madroñero, and F. Campuzano-Bolarín, "Implementing Industry 4.0 principles," Computers \& Industrial Engineering, vol. 158, p. 107379, Aug. 2021. https://doi.org/10.1016/j.cie.2021.107379

[6] Y. Shahzad, H. Javed, H. Farman, J. Ahmad, B. Jan, and M. Zubair, "Internet of Energy: Opportunities, applications, architectures and challenges in smart industries," Computers \& Electrical Engineering, vol. 86, p. 106739, Sep. 2020. https://doi.org/10.1016/j.compeleceng.2020.106739

[7] A. Sestino, M. I. Prete, L. Piper, and G. Guido, "Internet of Things and Big Data as enablers for business digitalization strategies," Technovation, vol. 98, p. 102173, Dec. 2020. https://doi.org/10.1016/j.technovation.2020.102173

[8] S. Nižetić, P. Šolić, D. López-de-Ipiña González-de-Artaza, and L. Patrono, “Internet of Things (IoT): 
Opportunities, issues and challenges towards a smart and sustainable future," Journal of Cleaner Production, vol. 274, p. 122877, Nov. 2020. https://doi.org/10.1016/j.jclepro.2020.122877

[9] C. Spence and F. M. Carvalho, "The coffee drinking experience: Product extrinsic (atmospheric) influences on taste and choice," Food Quality and Preference, vol. 80, p. 103802, Mar. 2020. https://doi.org/10.1016/j.foodqual.2019.103802

[10] N. Firmawati, G. Farokhi, and W. Wildian, "Rancang Bangun Mesin Pembuat Minuman Kopi Otomatis Berbasis Arduino UNO dengan Kontrol Android," JITCE (Journal of Information Technology and Computer Engineering), vol. 3, no. 01, pp. 25-29, Mar. 2019. https://doi.org/10.25077/jitce.3.01.25-29.2019

[11] L. Wibowo and W. Broto, "Pemanfaatan Mikrokontroler Dalam Mesin Pembuat Kopi," Prosiding SNF, vol. 6, pp. SNF2017-CIP, Oct. 2017. https://doi.org/10.21009/03.SNF2017.02.CIP.01

[12] M. S. Hadi, S. Ubaidilah, R. A. P. Sari, and D. P. Fatmala, "Sistem kendali otomatis mesin penetas telur menggunakan kontroler PID," Jurnal Teknologi, Elektro, dan Kejuruan, vol. 27, no. 2, pp. 116124, 2017. https://doi.org/10.17977/um034v27i2p116-124

[13] J. Mellado and F. Núñez, "Design of an IoT-PLC: A containerized programmable logical controller for the industry 4.0," Journal of Industrial Information Integration, p. 100250, Aug. 2021. https://doi.org/10.1016/j.jii.2021.100250

[14] A. Goeritno and S. Pratama, "Rancang-Bangun Prototipe Sistem Kontrol Berbasis Programmable Logic Controller untuk Pengoperasian Miniatur Penyortiran Material," Jurnal Rekayasa Elektrika, vol. 16, no. 3, pp. 198-206, 2020. https://doi.org/10.17529/jre.v16i3.14905

[15] D. Yuhendri, "Penggunaan PLC Sebagai Pengontrol Peralatan Building Automatis," Journal of Electrical Technology, vol. 3, no. 3, pp. 121-127, 2018. https://jurnal.uisu.ac.id/index.php/jet/article/view/952

[16] A. Rustandi and M. F. Ibrahim, "Simulasi Mesin Pencampur Kopi Otomatis dengan Metode Tunning PID pada LabVIEW Automatic Coffee Mixer Simulator with Tunning PID Methode on LabVIEW," vol. 4, no. 2, pp. 25-34, 2016. https://doi.org/10.34010/telekontran.v4i2.1887

[17] N. Mohammed and A. M. Saif, "Programmable logic controller based lithium-ion battery management system for accurate state of charge estimation," Computers \& Electrical Engineering, vol. 93, p. 107306, Jul. 2021. https://doi.org/10.1016/j.compeleceng.2021.107306

[18] S. Vadi, R. Bayindir, Y. Toplar, and I. Colak, "Induction motor control system with a Programmable Logic Controller (PLC) and Profibus communication for industrial plants - An experimental setup," ISA Transactions, Apr. 2021. https://doi.org/10.1016/j.isatra.2021.04.019

[19] K. Czerwiński, A. Wojtulewicz, and M. Ławryńczuk, "Fuzzy Controller for Laboratory Levitation System: Real-time Experiments Using Programmable Logic Controller," International Journal of Control, Automation and Systems 2019 17:6, vol. 17, no. 6, pp. 1507-1514, May 2019. https://doi.org/10.1007/s12555-018-0394-1

[20] R. D. Puriyanto, S. A. Akbar, and A. Aktawan, "Desain Sistem Biodiesel Berbasis Plc Berdasarkan Diagram Keadaan," Jurnal Ilmiah Teknik Elektro Komputer dan Informatika, vol. 4, no. 2, pp. 100109, 2018. https://doi.org/10.26555/jiteki.v4i2.12051

[21] Hendra, S. Pebriyanto, Hernadewita, Hermiyetti, and Yoserizal, "Applying Programmable Logic Control (PLC) for Control Motors, Blower and Heater in the Rubber Drying Processing," Jurnal Ilmiah Teknik Elektro Komputer dan Informatika, vol. 7, no. 1, pp. 131-141, 2021. https://doi.org/10.26555/jiteki.v7i1.20514

[22] Y. H. Cheng, P. J. Chao, H. Y. Liang, and C. N. Kuo, "Smart home environment management using programmable logic controller," Engineering Letters, vol. 28, no. 4, pp. 1174-1181, 2020. http://www.engineeringletters.com/issues_v28/issue_4/EL_28_4_24.pdf

[23] S. Yahya, S. W. Jadmiko, K. Wijayanto, and A. R. A. Tahtawi, "Design and implementation of training module for control liquid level on tank using PID method based PLC," IOP Conference Series: Materials Science and Engineering, vol. 830, no. 3, p. 032065, Apr. 2020. https://doi.org/10.1088/1757-899X/830/3/032065

[24] D.-A. Mocanu, V. Bădescu, C. Bucur, I. Ștefan, E. Carcadea, M. S. Răboacă, and I. Manta "PLC Automation and Control Strategy in a Stirling Solar Power System," Energies 2020, Vol. 13, Page 1917, vol. 13, no. 8, p. 1917, Apr. 2020. https://doi.org/10.3390/en13081917 
[25] S. Kadry and V. Rajinikanth, "Design of PID Controller for Magnetic Levitation System using Harris Hawks Optimization," Jurnal Ilmiah Teknik Elektro Komputer dan Informatika, vol. 6, no. 2, p. 70, 2021. https://doi.org/10.26555/jiteki.v6i2.19167

[26] T. P. Cabré, A. S. Vela, M. T. Ribes, J. M. Blanc, J. R. Pablo, and F. C. Sancho, "Didactic platform for DC motor speed and position control in Z-plane," ISA Transactions, 2021. https://doi.org/10.1016/j.isatra.2021.02.020

[27] S. Ekinci, B. Hekimoğlu, and D. Izci, "Opposition based Henry gas solubility optimization as a novel algorithm for PID control of DC motor," Engineering Science and Technology, an International Journal, vol. 24, no. 2, pp. 331-342, Apr. 2021. https://doi.org/10.1016/j.jestch.2020.08.011

[28] X. Jin, K. Chen, Y. Zhao, J. Ji, and P. Jing, "Simulation of hydraulic transplanting robot control system based on fuzzy PID controller," Measurement, vol. 164, p. 108023, Nov. 2020. https://doi.org/10.1016/j.measurement.2020.108023

[29] Q. Bu, J. Cai, Y. Liu, M. Cao, L. Dong, R. Ruan, and H. Mao, "The effect of fuzzy PID temperature control on thermal behavior analysis and kinetics study of biomass microwave pyrolysis," Journal of Analytical and Applied Pyrolysis, vol. 158, p. 105176, Sep. 2021. https://doi.org/10.1016/j.jaap.2021.105176

[30] L. Pan and X. Wang, "Variable pitch control on direct-driven PMSG for offshore wind turbine using Repetitive-TS fuzzy PID control," Renewable Energy, vol. 159, pp. 221-237, Oct. 2020. https://doi.org/10.1016/j.renene.2020.05.093

[31] C. Conker and M. K. Baltacioglu, "Fuzzy self-adaptive PID control technique for driving HHO dry cell systems," International Journal of Hydrogen Energy, vol. 45, no. 49, pp. 26059-26069, Oct. 2020. https://doi.org/10.1016/j.ijhydene.2020.01.136

[32] I. Carlucho, M. De Paula, and G. G. Acosta, "An adaptive deep reinforcement learning approach for MIMO PID control of mobile robots," ISA Transactions, vol. 102, pp. 280-294, Jul. 2020. https://doi.org/10.1016/j.isatra.2020.02.017

[33] H. Rahimi Nohooji, “Constrained neural adaptive PID control for robot manipulators," Journal of the Franklin Institute, vol. 357, no. 7, pp. 3907-3923, May 2020. https://doi.org/10.1016/j.jfranklin.2019.12.042

[34] W. Tang, L. Wang, J. Gu, and Y. Gu, "Single Neural Adaptive PID Control for Small UAV MicroTurbojet Engine," Sensors 2020, Vol. 20, Page 345, vol. 20, no. 2, p. 345, Jan. 2020. https://doi.org/10.3390/s20020345

[35] R. P. Borase, D. K. Maghade, S. Y. Sondkar, and S. N. Pawar, "A review of PID control, tuning methods and applications," International Journal of Dynamics and Control 2020 9:2, vol. 9, no. 2, pp. 818827, Jul. 2020. https://doi.org/10.1007/s40435-020-00665-4

[36] J. Możaryn, J. Petryszyn, and S. Ozana, "PLC based fractional-order PID temperature control in pipeline: design procedure and experimental evaluation," Meccanica 2020 56:4, vol. 56, no. 4, pp. 855-871, Aug. 2020. https://doi.org/10.1007/s11012-020-01215-0

[37] F. Meng, S. Liu, and K. Liu, "Design of an Optimal Fractional Order PID for Constant Tension Control System," IEEE Access, vol. 8, pp. 58933-58939, 2020. https://doi.org/10.1109/ACCESS.2020.2983059

[38] Kasmira, A. Waris, and M. T. Sapsal, "Rancang Bangun Sistem Kendali Kecepatan Putar Motor DC menggunakan PID Controller pada Mesin Pengaduk," AgriTechno, vol. 11, no. 1, pp. 81-92, 2018. https://doi.org/10.20956/at.v11i1.90

[39] Y.Zhi, W. Weiqing, C. Jing, and N. Razmjooy, "Interval linear quadratic regulator and its application for speed control of DC motor in the presence of uncertainties," ISA Transactions, Jul. 2021. https://doi.org/10.1016/j.isatra.2021.07.004

[40] B. N. Kommula and V. R. Kota, "Direct instantaneous torque control of Brushless DC motor using firefly Algorithm based fractional order PID controller," Journal of King Saud University Engineering Sciences, vol. 32, no. 2, pp. 133-140, Feb. 2020. https://doi.org/10.1016/j.jksues.2018.04.007

[41] E. Eker, M. Kayri, S. Ekinci, and D. Izci, "A New Fusion of ASO with SA Algorithm and Its Applications to MLP Training and DC Motor Speed Control," Arabian Journal for Science and Engineering, vol. 46, no. 4, pp. 3889-3911, Feb. 2021. https://doi.org/10.1007/s13369-020- 


\section{8-5}

[42] S. Ekinci, D. Izci, and B. Hekimoglu, "PID Speed Control of DC Motor Using Harris Hawks Optimization Algorithm," in 2nd International Conference on Electrical, Communication and $\begin{array}{llll}\text { Computer } \quad \text { Engineering, } & \text { ICECCE }\end{array}$ https://doi.org/10.1109/ICECCE49384.2020.9179308

[43] H. Yin, W. Yi, K. Wang, J. Guan, and J. Wu, "Research on brushless DC motor control system based on fuzzy parameter adaptive PI algorithm," AIP Advances, vol. 10, no. 10, p. 105208, Oct. 2020. https://doi.org/10.1063/5.0025000

[44] F. Auliansyah, Sutedjo, O. Asrarul Qudsi, and I. Ferdiansyah, "Controlling speed of brushless dc motor by using fuzzy logic controller," Proceedings - 2020 International Seminar on Application for Technology of Information and Communication: IT Challenges for Sustainability, Scalability, and Security in the Age of Digital Disruption, iSemantic 2020, pp. 298-304, Sep. 2020. https://doi.org/10.1109/iSemantic50169.2020.9234290

[45] L. Zhou, F. Jiang, J. She, and Z. Zhang, "Generalized-extended-state-observer-based Repetitive Control for DC Motor Servo System with Mismatched Disturbances," International Journal of Control, Automation and Systems, vol. 18, pp. 1936-1945, Jan. 2020. https://doi.org/10.1007/s12555-019-0578-3

[46] A. K. Kumawat, R. Kumawat, M. Rawat, and R. Rout, "Real time position control of electrohydraulic system using PID controller," Materials Today: Proceedings, vol. 47, pp. 2966-2969, Jan. 2021. https://doi.org/10.1016/j.matpr.2021.05.203

[47] S. M. H. Mousakazemi, "Computational effort comparison of genetic algorithm and particle swarm optimization algorithms for the proportional-integral-derivative controller tuning of a pressurized water nuclear reactor," Annals of Nuclear Energy, vol. 136, p. 107019, Feb. 2020. https://doi.org/10.1016/j.anucene.2019.107019

[48] M. F. Al Andzar and R. D. Puriyanto, "PID Control for Temperature and Motor Speed Based on PLC," Signal and Image Processing Letters, vol. 1, no. 1, pp. 7-13, Mar. 2019. https://doi.org/10.31763/simple.v1i1.150 